UDC: $616-006.5 / .55-031.81-056.7 / .76-02: 616-053-055(477.83)$

\title{
Familial adenomatous polyposis: age of onset and association with mutations of the $A P C$ gene in patients from West Ukraine
}

\author{
M. R. Lozynska ${ }^{4}$, Y. S. Lozynskyy ${ }^{1}$, A. Plawski², R. O. Pinyazhko ${ }^{1}$, \\ N. M. Prokopchuk ${ }^{4}$, O. M. Fedota ${ }^{3}$ \\ ${ }^{1}$ Danylo Halytsky Lviv National Medical University \\ 69, Pekarska Str., Lviv, Ukraine, 79010 \\ ${ }^{2}$ Institute of Human Genetics of Polish Academy of Sciences \\ 32, Strzeszynska Str., Poznan, Poland, 60-479 \\ ${ }^{3}$ V. N. Karazin Kharkiv National University \\ 4, Svobody Sq., Kharkiv, Ukraine, 61077 \\ ${ }^{4}$ State Institution "Institute of Hereditary Pathology, NAMS of Ukraine" \\ 31a, M. Lysenko Str., Lviv, Ukraine, 79008 \\ maria_lozynska@ukr.net
}

\begin{abstract}
Aim. To evaluate the average age of familial adenomatous polyposis (FAP) onset in both males, females and in their relatives, carriers or not carriers of the $A P C$ gene mutations, to estimate the anticipation in successive generations for early identification of the individuals in the risk group. Methods. The medical records, genealogical information were gathered and molecular genetic study of blood was carried out in 25 probands with adenomatous polyposis. FAP was confirmed in $44.0 \%$ of probands. The probands with FAP had 36 affected relatives. The amplified fragments of the $A P C$ gene were screened for the mutations involving heteroduplex analysis an d detection of single-stranded conformational polymorphism, heteroduplex analysis, and also high resolution melting analysis. The age of FAP onset was evaluated in probands and their relatives. The anticipation index (A) was calculated. Results. Among patients with FAP $61.7 \%$ were males and $38.3 \%$ were females. The age of FAP onset in males was $36.0 \pm 1.4$ years, while in females the disease manifested earlier - in $29.5 \pm 2.4$ years $(p<0.01)$. The APC mutations, including four novel mutations, were found in $63.6 \%$ of probands with FAP. The lowest age of polyposis onset was observed in carriers of the APC mutation c.3927 3931delAAAGA p.Q1309fs. The average age difference between FAP onset in the parents and their offspring was $12.0 \pm 1.7$ years. In 3 of 4 families with FAP and novel mutations of the $A P C$ gene predominance of males (12:4) and anticipation phenomenon were observed.The strongest age correlations of FAP onset were found in mother-offspring pairs and parents-son pairs. The statistically significant difference between the data confirmed more similarities of descendant, especially sons, with parents. Conclusions. There was no statisti-
\end{abstract}

C 2017 M. R. Lozynska et al.; Published by the Institute of Molecular Biology and Genetics, NAS of Ukraine on behalf of Biopolymers and Cell. This is an Open Access article distributed under the terms of the Creative Commons Attribution License (http://creativecommons.org/licenses/by/4.0/), which permits unrestricted reuse, distribution, and reproduction in any medium, provided the original work is properly cited 
cally significant difference between average age of the disease onset in patients carriers of the $A P C$ mutations $(33.1 \pm 2.1$ years $)$ and in patients without the $A P C$ mutations studied by the traditional methods $(33.7 \pm 1.6$ years). In offsprings with FAP the reduced age of disease onset compared to the parents was revealed irrespective of the presense of the $A P C$ mutations. The anticipation index in FAP was $18.0 \%$. Accounting anticipation allows estimating the approximate average age at FAP onset during genetic counseling, and therefore timely to carry out targeted prevention.

Ke y w o r d s: anticipation, $A P C$ mutations, age of FAP onset in males and females, familial adenomatous polyposis.

\section{Introduction}

The most common adenomatous polyposis disorders include familial adenomatous polyposis (FAP), attenuated FAP (AFAP), and other multiple colorectal adenomatous syndromes - MUTYH-associated polyposis (MAP), NTHL1-associated polyposis (NAP) and polymerase proofreading-associated polyposis (PPAP). Genetical and clinical manifestations of the polyposis syndromes vary, and cases with clinical diagnosis of FAP «might molecularly be presented by different diagnosis» $[1,2]$. A classic FAP (MIM No. $175000)$ is an autosomal dominantly inherited disease characterized by the development of hundreds to thousands of colorectal adenomatous polyps after the first decade of life and affects both genders. FAP is an orphan disease: estimates of the prevalence of syndrome vary from $1: 6,850$ to $1: 31,250$ live births and account for $0.2 \%-1.0 \%$ of all colorectal cancer (CRC) [3-4]. The risk of CRC is virtually $100 \%$ by the 50 years for the classic form of this syndrome. FAP is the second most common inherited CRC syndrome. Many FAP patients show extracolonic tumors (hepatoblastoma, cancer of thyroid glands and brain, desmoid and pancreatic tumors), which can contribute to morbidity and mortality [4-5].
The average age of onset for FAP is 35.9 (22-63) years [6]. Most classic FAP cases arise as a consequence of a germline heterozygous mutation in the adenomatous polyposis coli gene $(A P C)$, a tumor suppressor gene located on chromosome 5 (5q21). The coding region is divided into 15 exons and encodes a large protein (309 kilo-Daltons) [7]. The $A P C$ gene plays several important roles in cells, influencing cell adhesion, cytoskeleton and cell cycle [8]. Since the first description in 1986 by Herrera L. et al., over 1000 mutations have been found, which are inserted into the international reference database. About $25 \%$ of people with FAP do not have any family history of the disease and harbour a de novo mutation in the $A P C$ gene without any clinical or genetic evidence of FAP in the family $[9,10]$. Conventional techniques leave approximately $30 \%$ of families with classical FAP and approximately $90 \%$ of AFAP families $A P C$ mutation-negative [11]. There remains a high proportion of $A P C$ mutation negative patients even after extensive searches for new causative genes. $25 \%$ of $A P C$ mutation negative samples were found to harbour pathogenic mutations in MUTYH $[12,13]$. Differential diagnoses include other disorders causing multiple polyps (such as PeutzJeghers syndrome, familial juvenile polyps or 
hyperplastic polyposis, hereditary mixed polyposis syndromes).

In patients with FAP the first symptoms are often manifested in puberty. These include dyspepsia with frequent liquid defecation, abdominal pain, anemia, metabolic disorders leading to a delay in physical development [14]. The earlier FAP is manifested, the severer is its course, and the sooner decompensation state follows [15]. The overall sex ratio among affected individuals was $55 \%: 45 \%$ (male:female) with similar ratios in the $A P C$ positive and $A P C$ negative groups (57\%:43\% and $51 \%: 49 \%$, respectively) [6]. However, a mutation of the $A P C$ gene is stable, and the site of mutation determines the severity or associated features of FAP with strong parent-child correlation [16].

In families with FAP a phenomenon of genetic anticipation was observed, in which the age of onset of a disorder reduced and/or the severity of the phenotype increased in successive generation [17]. For along time, geneticists were skeptical on the real existence of the phenomenon. Clinical anticipation for diseases onset has been reported since the $19^{\text {th }}$ century. Nowadays, this phenomenon has a molecular genetic evidence. In 1991 the trinucleotide expansion mechanism was first identified in a group of inherited neuromuscular disorders [18]. This phenomenon is commonly encountered in human dominant type hereditary disorders, such as Von HippelLindau [19] and Li-Fraumeni syndromes [20]. The evidence for genetic anticipation has been described in some cancer genetic syndromes like breast cancer [21], pancreatic cancer [22], ovarian cancer [23], CRC [24], leukemia [25], lymphoma [26], melanoma [27]. In 1994,
Shibata et al. were the first to suggest that younger onset of cancer observed in consecutive generations of Lynch families could be explained by the accumulation of mismatch repair slippage events due to the diminished DNA mismatch repair proficiency. A few years later, the same group using a mathematical model hypothesized that the number of mutations accumulated in a tumor was dependent on the mutation rate and the number of cell division [28]. According to the modern concepts, an increased risk of a variety of tumors and genetic anticipation are associated with the telomere length changes [29-30].

The aim of the study was to evaluate the average age of FAP onset of males and females and in their relatives, carriers or not carriers of the $A P C$ gene mutations, in successive generations to estimate the anticipation for early identification of the individuals in the risk group.

\section{Methods}

In the period from 2002 to 2015 year the medical records and genealogical information from 25 probands with adenomatous polyposis were analyzed. FAP was confirmed in 10 $(40.0 \%)$ probands with adenomatous polyposis and a family history of the disease or a family history of the malignant tumors associated with the syndrome (CRC, gastric cancer or pancreatic cancer). One proband (the $A P C$ mutation carrier) from the FAP group had neither clinical nor genetic evidence of FAP in family members, so we assumed she carried the de novo mutation of the $A P C$ gene. The probands with FAP had 36 affected relatives. The individuals with 100 or more adenomatous polyps as well as those with fewer than 
100 adenomatous polyps and a family history of FAP are clinically diagnosed as FAP according to the diagnostic criteria. The genealogical information in 3-4 generations was collected using a single registration of probands according to the appropriate ethical requirements. The mode of inheritance of the diseases was determined using the clinical, genealogical, laboratory and literature (OMIM) database. The age of FAP onset was evaluated in the probands and in their relatives. The patients were residents of five regions of Ukraine: Lviv, Ivano-Frankivsk, Ternopil, Volyn and Chernivtsi.

The molecular genetic study in 25 probands with adenomatous polyposis and in 4 their relatives was carried out. Genomic DNA was isolated from peripheral blood using a saltingout method [31]. Before blood sampling for molecular genetic studies, the informed consent to perform such analysis was obtained from patients. The primers, described by Prosser et al., were used including individual exonic splicing sites.

DNA samples of all the patients tested for the presence of small mutations using screening methods such as strand conformational polymorphism methods (SSCP), heteroduplex analysis (HD), and also high resolution melting (HRM). Our study included patients whose gene fragments (or entire genes) had undergone large rearrangements as well as those in which small mutations had been detected.

We screened the $A P C$ gene fragments that encompassed exons 5-8, exons 10-14, and the fragment from A to L of exon 15 for mutations with heteroduplex analysis (HD) and single strand conformational polymorphism methods (SSCP) [32]. Parameters influencing
SSCP analysis: DNA amplification, denaturation, and the electrophoretic conditions. Another important aspect of SSCP analysis is the visualization of the single-stranded DNA fragments. In brief, after electrophoresis, the PAAG are first fixed with $10 \%$ acetic acid for approximately $30 \mathrm{~min}$ at room temperature and subsequently washed with water. Depending on the concentration of silver nitrate, incubation with the silver nitrate solution can last for approximately $60 \mathrm{~min}$ (in a $0.001 \%$ AgNO3, $0.036 \%$ formaldehyde solution). This incubation step is performed in the dark, while avoiding any contamination with protein-containing solution. Subsequently, the PAAG are washed with water and color development is performed by incubating the gel for 5 to $10 \mathrm{~min}$ with a color development solution (containing $2.5 \% \mathrm{Na}_{2} \mathrm{CO}_{3}, 0.036 \%$ formaldehyde, and $0.002 \%$ sodium thiosulfate). Color development can be stopped with a solution containing a chelating agent (such as $1.5 \%$ EDTA). Gels can be subsequently fixed with $30 \%$ ethanol and $4 \%$ glycerol. The stained gels are transferred to a vacuum dryer and are immobilized to a porous paper. Results are can be analyzed by means of an image analysis system.

All mutations were verified by the DNA sequence determination from both the 5 and 3 directions. PCR was carried out in the same way as for the SSCP/HD analyses using the same PCR primers. The DNA fragments that showed heteroduplex in HD analysis or additional patterns in SSCP analysis were sequenced by direct PCR product sequencing and analysed with ALF Express (Amersham Pharmacia Biotech, Uppsala, Sweden) according to the manufacturer's specifications [33]. 


\section{C-HRM primers}

We designed sets of primers for a simultaneous amplification of a reference fragment (with an unchanged number of copies) and a target fragment (with $A P C$ gene fragments as its template). Designed primers for the $A P C$ gene (fragments of exons 9, 14 and 15) include large rearrangements and also small sequence changes detected in our group of patients. Primers were designed using the Primer3plus (www.bioinformatics.nl/primer3plus/) software. The melting temperature of all primers was in the range of $58.0-62.3{ }^{\circ} \mathrm{C}$ (Table 1).

Subsequently, the primer pairs were selected for a multiplex reaction, with one of the products including the target fragment of the studied gene and the second one as a reference. Amplicons were paired in respect of their melting temperature ranges (no overlaps between the amplicons) and lack of non-specific interactions between primers that could impair the amplification efficiency.

Assay design: the products were amplified using the type-it HRM kit (Qiagen) on the DNA templates at a concentration of $50 \mathrm{ng} / \mu \mathrm{l}$ diluted in AE buffer (Qiagen). The analysis was performed on a Rotor-Gene ${ }^{\circledR} \mathrm{Q}$ equipment (Qiagen). PCR reactions were carried out for the 30 cycles (with a 5 min preincubation at $95^{\circ} \mathrm{C}$ ) of $95{ }^{\circ} \mathrm{C}$ for $10 \mathrm{~s}, 55^{\circ} \mathrm{C}$ for $30 \mathrm{~s}$ and $72{ }^{\circ} \mathrm{C}$ for $10 \mathrm{~s}$, the products were then melted and PCR was continued to the 40th cycle in the same conditions followed by another melting process. The first melting analysis was performed from $70{ }^{\circ} \mathrm{C}$ to $90^{\circ} \mathrm{C}$ by raising the temperature by $0.3^{\circ}$ at each step after which the second one, designed to detect small changes in the sequence, was carried out with higher resolution raising the temperature by $0.1^{\circ}$ at each step.

Anticipation index (A) was calculated using the formula:

$$
A=(P-D) /(P+D) \text {, }
$$

$P$ - age of disease onset in one parent, $D$ - age of disease onset in offsprings [34].

Statistical analysis had been carried out using Shapiro-Wilk test for normality, Student's $\mathrm{t}$ Test and Spearman correlation.

\section{Results and Discussion}

The characteristics of probands and their relatives with FAP by gender and age at polyposis onset are shown in table 2.

\section{Table 1. Sets of primers}

\begin{tabular}{|c|c|c|c|c|c|c|c|}
\hline $\begin{array}{l}\text { Studied } \\
\text { exon }\end{array}$ & 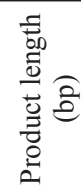 & Forward primer & $\begin{array}{l}\mathrm{Tm} \\
\left({ }^{\circ} \mathrm{C}\right)\end{array}$ & $\begin{array}{c}\text { Final } \\
\text { concen- } \\
\text { tration } \\
\text { (nM) }\end{array}$ & Reverse primer & $\begin{array}{l}\text { Tm } \\
\left({ }^{\circ} \mathrm{C}\right)\end{array}$ & 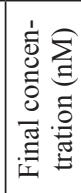 \\
\hline $\begin{array}{l}9 \text { Target } \\
\text { amplicon }\end{array}$ & 249 & GCCCACAGGTGGAAATGG & 62.3 & 172 & GAATGATGTTGTGGAGTGCTG & 59.2 & 172 \\
\hline $\begin{array}{l}14 \text { Target } \\
\text { amplicon }\end{array}$ & 239 & GAAGTTAATGAGAGACAAATTCCA & 58.0 & 172 & TCCGTAATATCCCACCTCCA & 60.1 & 172 \\
\hline $\begin{array}{l}15 \text { Target } \\
\text { amplicon }\end{array}$ & 180 & TCTGCTGCCCATACACATTC & 59.7 & 688 & GGATTCAATCGAGGGTTTCA & 59.9 & 688 \\
\hline
\end{tabular}


Table 2. The characteristics of probands and their relatives with familial adenomatous polyposis by the gender and the age of polyposis onset

\begin{tabular}{|c|c|c|c|c|c|}
\hline \multirow{2}{*}{ Probands } & \multirow{2}{*}{ Gender of probands } & \multirow{2}{*}{ Age (years) } & \multicolumn{2}{|c|}{$\begin{array}{l}\text { Number of the relatives of } \\
\text { probands }\end{array}$} & \multirow{2}{*}{$\begin{array}{c}\text { Age of polyposis onset in the relatives } \\
\text { of probands (years) }\end{array}$} \\
\hline & & & males & females & \\
\hline 1. A & $\mathrm{f}$ & 24 & - & - & - \\
\hline 2. $\mathrm{B}$ & $\mathrm{f}$ & 28 & 1 & 0 & 46 \\
\hline 3. $\mathrm{C}$ & f & 32 & 5 & 3 & $41,32,42,33,32,45^{*}, 40^{*}, 19^{*}$ \\
\hline 4. $\mathrm{D}$ & $\mathrm{f}$ & 26 & 2 & 0 & 28,43 \\
\hline 5. E & $\mathrm{f}$ & 15 & 1 & 1 & $40,16^{*}$ \\
\hline 6. F & $\mathrm{f}$ & 32 & 4 & 1 & $43,33,26,32,45^{*}$ \\
\hline 7. G & $\mathrm{f}$ & 36 & 3 & 1 & $24,32,40,18^{*}$ \\
\hline 8. $\mathrm{H}$ & $\mathrm{f}$ & 44 & 1 & 0 & $?$ \\
\hline 9. I & $\mathrm{f}$ & 29 & 3 & 2 & $32,35,30,31^{*}, 31^{*}$ \\
\hline 10. J & $\mathrm{m}$ & 36 & 5 & 1 & $48,45,32,41,19,20^{*}$ \\
\hline 11. $\mathrm{K}$ & $\mathrm{m}$ & 48 & 2 & 0 & $40,(?)$ \\
\hline Total & 9 females $/ 2$ males & 31.8 & 27 & 9 & 27 males / 9 females \\
\hline
\end{tabular}

Note. ${ }^{*}$ - marked females, (?) - the age of polyposis onset is uknnown.

Among the patients with FAP 29 (61.7\%) were males and $18(38.3 \%)$ were females, whereas women dominated among probands with polyposis (Table 2).

The age of patients ranged from 15 to 48 years. The age of FAP onset in males was $36.0 \pm 1.4$ years of age, whereas in females disease manifested earlier - at $29.5 \pm 2.4$ years of age $(\mathrm{t}=2.69, p<0.01)$. The average age of FAP onset was $32(15-48)$ years and was lower compared to the data given in the literature $36(22-63)$ years [6].

The $A P C$ mutations, including four novel mutations, were found in 7 (63.6\%) probands with FAP and 6 of them were females of 7 families with FAP (table 3). Other 4 (16.0\%) probands with familial anamnesis of polyposis and cancer had no mutations. Among mutation carriers were 8 females and 3 males (probands and their relatives). The lowest age of polyposis onset was observed in carriers of the $A P C$ mutation c.3927_3931delAAAGA p.Q1309fs. The mutation leads to premature termination of the $A P C$ gene protein product $[35,36]$. This deletion is one of the most frequent $A P C$ mutations in Europe $[14,33]$. In most cases the mutation in codon 1309 leads to early onset of the disease accompanied by hundreds of polyps at a young age, early occurrence of CRC and extracolonic manifestations [14].

There was no statistically significant difference between average age of the disease onset in patients carriers of the $A P C$ mutations $(33.1 \pm 2.1$ years $)$ and in patients without the $A P C$ mutations identified by traditional methods (33.7 \pm 1.6 years). In 3 of 4 families with FAP and novel mutations of the $A P C$ gene (probands 4D, 6F, 10J, table 2, 2) predomi- 
Table 3. The $A P C$ mutations in families with familial adenomatous polyposis and the average age of the syndrome onset within the families

\begin{tabular}{|c|c|c|c|c|c|}
\hline 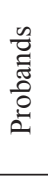 & $\begin{array}{l}\text { № of } \\
\text { exons }\end{array}$ & Mutations & $\begin{array}{l}\text { The evarage age } \\
\text { of FAP onset in } \\
\text { patients within the } \\
\text { family }(*)\end{array}$ & $\begin{array}{l}\text { Number of } \\
\text { patients with FAP } \\
\text { within the family }\end{array}$ & $\begin{array}{c}\text { Number of } \\
\text { patients those } \\
\text { identified } \\
\text { mutations within } \\
\text { the family }\end{array}$ \\
\hline A & 15 & c.3931_3946delATTGGAACTAGGTCG & 24,0 & 1 & 1 \\
\hline B & 5 & c. $532-1 \mathrm{G}>\mathrm{A} * *$ & 39,5 & 2 & 1 \\
\hline $\mathrm{D}$ & $11-14$ & deletion of exons & $36,5 \pm 6,7$ & 3 & 1 \\
\hline $\mathrm{E}$ & 15 & c.3927_3931delAAAGA p.Q1309fs & $23,7 \pm 8,1$ & 3 & 2 \\
\hline $\mathrm{F}$ & 15 & c. $2021 T>T A G$ & $35,8 \pm 3,6$ & 5 & 2 \\
\hline $\mathrm{H}$ & 6 & c. $697 \mathrm{C}>\mathrm{T} * *$ & 44,0 & 2 & 1 \\
\hline $\mathrm{J}$ & 15 & c.3343delA p.R1114fs & $34,0 \pm 4,7$ & 7 & 3 \\
\hline
\end{tabular}

Note. ${ }^{*}$ - The average age of FAP onset in all affected individuals within the family; ** - splice site mutations. Cursive marked mutations were not found in other ethnic groups.

nance of males with FAP (12:4) and anticipation phenomenon were observed. One proband (1A) with the $A P C$ gene mutation had neither clinical nor genetic evidence of FAP in family members, so she was supposed to carry the $d e$ novo mutation. The example of anticipation in the family with the novel c.3343delA p. R1114fs $A P C$ mutation is shown in Fig. 1 (patient 10J, table 2,2). Six relatives of the tient $3 \mathrm{C}$, table 2).

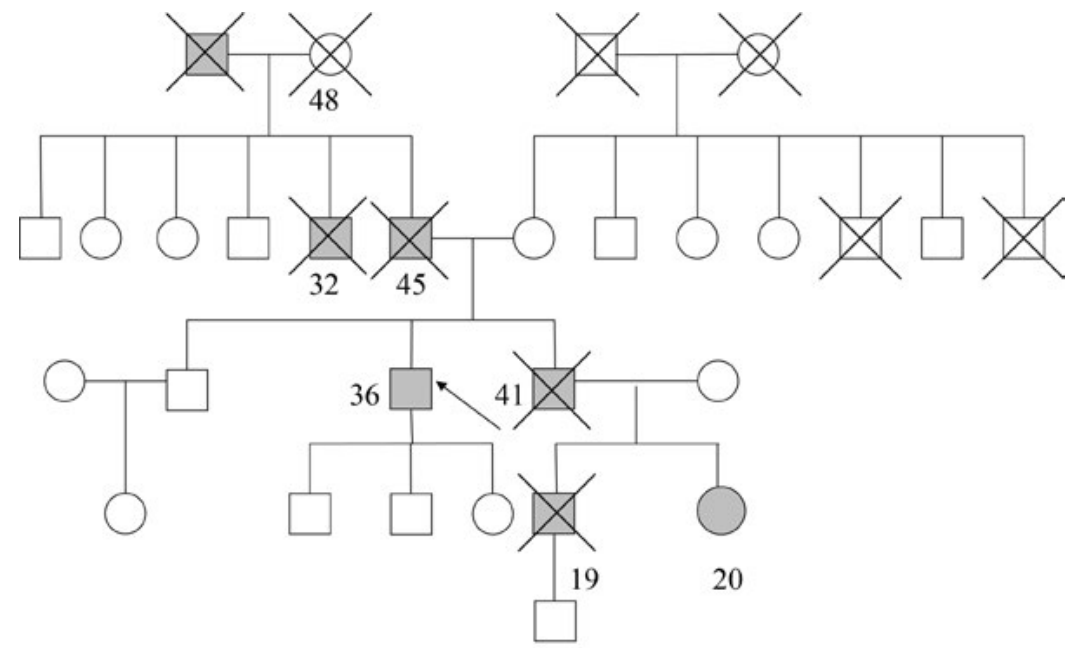

proband had FAP and 5 of them were males. Both earlier FAP onsets, the increased severity in offsprings, and the predominance of males among patients were observed in this affected family.

The example of anticipation in the family pedigree without the $A P C$ mutations confirmed by traditional methods is shown in Fig. 2 (pa-
Fig. 1. Pedigree of the proband and his relatives with FAP carriers of $A P C$ c.3343delA p.R1114fs mutation. 


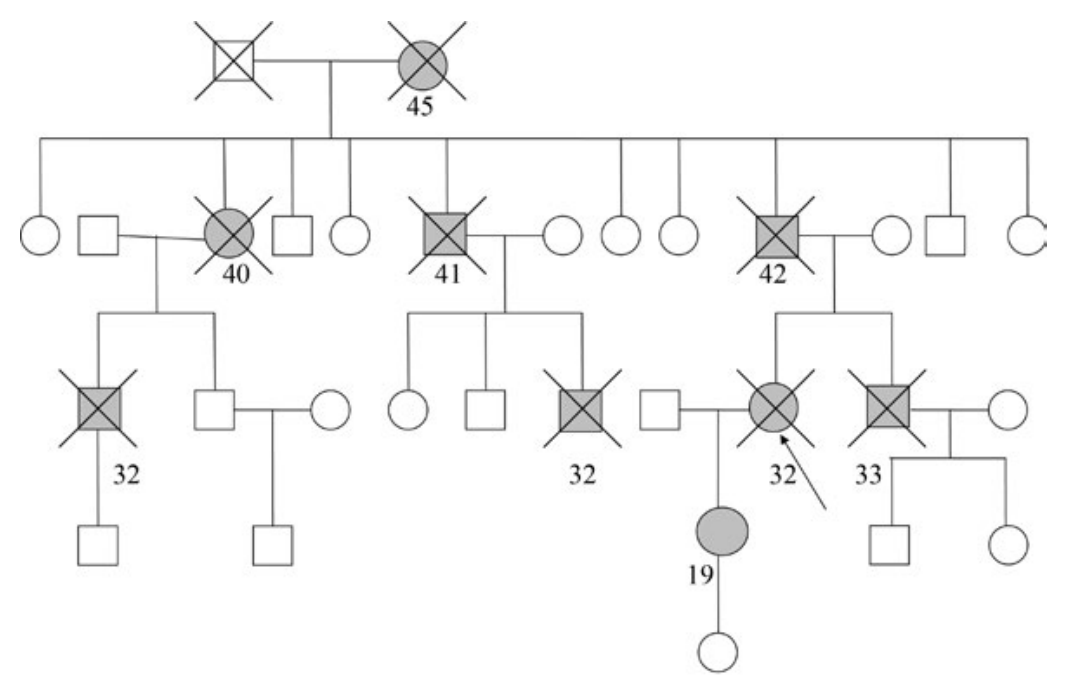

Fig. 2. Pedigree of the proband and her relatives with $A P C$ mutationnegative case of polyposis
Eight relatives of the proband had FAP. It is widely accepted that the methods used to identify mutations fail to detect certain mutations because of the factors such as polymorphisms in the sequences to which PCR primers bind that leads to allele dropout, or due to somatic mosaicism or because the mutations occur in the regions not targeted by the currently used methods. Castellsague et al. [37] and Spier et al. [38] reported the occurrence of imbalanced allele-specific expression of $A P C$ in $8 \%-9 \%$ of the $A P C$ mutation-negative polyposis cases, indicating that the underlying mutations were not detected by standard mutation detection techniques. Some of these cases carried pathogenic deep intronic variants predicted to activate cryptic splice sites [38], whereas others carried mutations in the promoter region of $A P C$ [39].

In offsprings with FAP the reduced age of disease onset compared to parents was revealed irrespective of the presense of the $A P C$ mutations. Analysis of the age of FAP onset in the probands and their affected relatives is shown in Table 4.

In most couples "parents-offspring" with FAP in offspring, the disease begins at an earlier age comparing to the parents with statistically significant difference. The average difference of the age of FAP onset and index of anticipation in the parents and their offspring are shown in Table 5.

The average age difference between the FAP onset in the parents and their offspring was $12.0 \pm 1.7$ years. The number of fatherdaughter pairs and father-son pairs was greater than the number of mother-daughter pairs and mother-son pairs. The anticipation index (A) in FAP was $18.0 \%$. This index ranges from $12.0 \%$ in pairs father-son to $25.0 \%$ - in pairs father-daughter in different family couples.

The highest values of anticipation index (A) in the FAP were in father-daughter pairs. The anticipation phenomenon in FAP was shown by any parent-child pairing methods for the 
M. R. Lozynska, Y. S. Lozynskyy, A. Plawski et al.

Table 4. The average age of familial adenomatous polyposis onset in family couples

\begin{tabular}{|l|c|c|c|c|}
\hline \multirow{2}{*}{ Family couples } & \multirow{2}{*}{$\mathrm{n}$} & \multicolumn{2}{|c|}{ The average age of FAP onset, $\mathrm{x} \pm \mathrm{s}_{\mathrm{x}}$} & \multirow{2}{*}{$p$} \\
\cline { 3 - 4 } & & parents & offsprings & $<0.001$ \\
\hline Parents-offspring & 20 & $40.8 \pm 1.6$ & $28.8 \pm 1.9$ & $<0.001$ \\
Parents-daughter & 10 & $39.1 \pm 1.9$ & $24.8 \pm 2.1$ & $<0.01$ \\
Parents -son & 10 & $42.4 \pm 2.4$ & $32.8 \pm 2.7$ & $<0.05$ \\
Mother-daughter & 2 & $32.5 \pm 0.5$ & $24.0 \pm 5.0$ & $<0.01$ \\
Mother-son & 2 & $42.5 \pm 10.5$ & $31.5 \pm 4.5$ & $<0.001$ \\
Father-daughter & 8 & $40.8 \pm 2.0$ & $25.0 \pm 2.4$ & $<0.05$ \\
Father-son & 8 & $42.4 \pm 2.3$ & $33.1 \pm 3.3$ & $>0.05$ \\
Mother-offspring & 4 & $37.5 \pm 5.2$ & $27.8 \pm 3.5$ & $<0.001$ \\
Father-offspring & 16 & $41.6 \pm 1.5$ & $29.1 \pm 2.2$ & \\
\hline
\end{tabular}

Note. $\mathrm{n}$ - the number of pairs of relatives, $\mathrm{x}^{ \pm} \mathrm{S}_{\mathrm{x}}$ - the average age of FAP onset and its statistical error, $p$ - statistical significance.

deceased in literature data: in the patients over 5 years of age, the mean age at death was 50.9 years for the parent, 42.3 years for the

Table 5. The average difference of the age of familial adenomatous polyposis onset and the anticipation index in parents and their offspring

\begin{tabular}{|l|c|c|c|}
\hline \multirow{2}{*}{ Family couples } & \multicolumn{2}{|c|}{$\begin{array}{c}\text { The average difference } \\
\text { of the age of FAP onset } \\
\text { (years) }\end{array}$} & $\begin{array}{c}\text { Anticipation } \\
\text { index, (\%) }\end{array}$ \\
\cline { 2 - 4 } & $\mathrm{n}$ & $\mathrm{d} \pm \mathrm{sd}$ & $A \pm \mathrm{s} a$ \\
\hline Parents-offspring & 20 & $12.0 \pm 1.7$ & $18.0 \pm 3.1$ \\
Parents-daughter & 10 & $13.5 \pm 2.6$ & $23.2 \pm 3.2$ \\
Parents-son & 10 & $8.5 \pm 2.3$ & $13.7 \pm 3.4$ \\
Father-daughter & 8 & $15.8 \pm 3.2$ & $25.0 \pm 0.1$ \\
Father-son & 8 & $9.3 \pm 2.7$ & $12.0 \pm 0.1$ \\
Father-offspring & 16 & $12.5 \pm 2.0$ & $18.0 \pm 3.6$ \\
Mother-daughter & 2 & $8.5 \pm 4.5$ & $16.0 \pm 9.5$ \\
Mother-son & 2 & $11.0 \pm 6.0$ & $14.0 \pm 5.5$ \\
Mother-offspring & 4 & $9.8 \pm 4.0$ & $15.0 \pm 4.5$ \\
\hline
\end{tabular}

Note. $\mathrm{n}$ - the number of pairs of relatives, $\mathrm{d} \pm \mathrm{sd}-$ the average age of FAP onset and its statistical error, $A \pm \mathrm{s} a$ - the average age of anticipation and its statistical error. proband, and 33.3 years for the child generations, respectively, $p<0.001$ [17].

The correlation coefficients for the age of FAP onset in parents and offspring are shown in Table 6.

The strongest age correlations of FAP onset were found in mother-offspring (mother-

Table 6. The correlation coefficients between the age values of familial adenomatous polyposis onset in relatives of probands

\begin{tabular}{|l|c|c|c|c|}
\hline \multicolumn{1}{|c|}{ Family couples } & $\mathrm{n}$ & $\mathrm{r}$ & $\mathrm{t}$ & $p$ \\
\hline Mother-daughter & 2 & 1 & - & - \\
Mother-son & 2 & 1 & - & - \\
Mother-offspring & 4 & $0.80 \pm 0.42$ & 1.912 & $<0.05$ \\
Father-daughter & 8 & $-0.01 \pm 41$ & -0.036 & $>0.05$ \\
Father-son & 8 & $0.57 \pm 0.34$ & 1.702 & $<0.01$ \\
Father-offspring & 16 & $0.36 \pm 0.25$ & 1.466 & $<0.01$ \\
Parents-daughter & 10 & $0.04 \pm 0.35$ & 0.113 & $>0.5$ \\
Parents-son & 10 & $0.58 \pm 0.29$ & 2.013 & $<0.01$ \\
Parents-offspring & 20 & $0.44 \pm 0.21$ & 2.059 & $<0.01$ \\
\hline
\end{tabular}

Note. $\mathrm{n}$ - number of pairs; $\mathrm{r}$-correlation coefficients; $\mathrm{t}-$ Student test; $p$ - value level of significance. 
daughter and mother-son) pairs and parentsson pairs. The statistically significant difference between the data confirmed more similarities of descendant, especially sons, with parents.

L.Roger et al. [40] suggest that the occurrence of the anticipation phenomenon is associated with the erosion of telomeres. The erosion of telomeres, mainly because of cell proliferation, may be accelerated by specific alterations in the genes involved in CRC, such as the $A P C$ gene [24]. Telomere/telomerase interplay is an important mechanism involved in both genomic stability and cellular replicative potential, and its dysfunction plays a key role in the oncogenetic process [30]. There is general agreement that the shortening of telomeres plays a role in the early steps of CRC carcinogenesis by promoting chromosomal instability (CIN). The $A P C$ mutation and activation of the Wnt pathway in colonic epithelial cells with long telomeres give rise to adenomas with long telomeres; these telomeres are stable and not prone to fusion [41].

The $A P C$ gene mutation in cells with short telomeres gives rise to adenomas with short telomeres that have a propensity to undergo fusion; the resulting CIN leads to the largescale genomic rearrangements that can drive the progression to malignancy. These data therefore indicate that telomere erosion precedes the initiation of colorectal adenomagenesis, and this may provide a mechanism contributing to the age-associated profile of colorectal carcinomas [40]. In vitro, hormones and growth factors affect telomerase activity. The sex hormones directly increase the telomerase reverse transcriptase (TERT) transcription and the telomerase activity in human cells
$[42,43]$. Natural and synthetic androgens can restore telomerase activity to normal levels in the cells in patients with TERT and TERC mutations can be directly activated by the tumor-suppressor protein c-Myc [44]. The rate of terminal restriction fragment length shortening per year in men was found to be significantly greater than that in women [45]. An estrogen-responsive element is present in TERT, so the hormone can stimulate telomerase [46]. This might reduce the shortening of a telomere.

Accounting anticipation has prognostic value, since it allows estimating an approximate average age of FAP onset during the genetic counseling providing timely targeted prevention. Due to autosomal dominant inheritance and high penetrance of FAP, the probands and their first degree relatives should be screened regularly by geneticist and oncologist. The cancer prevention and maintaining a good quality of life are the main goals of management and regular and systematic follow-up and supportive care should be offered to all patients.

\section{REFERENCES}

1. Urso EDL, Delaini GG, Campi M, Bacchelli C, Pucciarelli S. Colorectal polyposis: clinical presentation and surgical treatment. Colorectal Disease. 2014;17(1):61-6.

2. Talseth-Palmer BA. The genetic basis of colonic adenomatous polyposis syndromes. Hered Cancer Clin Pract. 2017;15:5.

3. Valle L. Genetic predisposition to colorectal cancer: where we stand and future perspectives. World $J$ Gastroenterol. 2014;20(29):9828-49.

4. Bülow S, Faurschou Nielsen T, Bülow C, Bisgaard ML, Karlsen L, Moesgaard F. The incidence rate of familial adenomatous polyposis. Results from 
the Danish Polyposis Register. Int J Colorectal Dis. 1996;11(2):88-91.

5. de la Chapelle A. Genetic predisposition to colorectal cancer. Nat Rev Cancer. 2004;4(10):769-80.

6. Acar T, Kumkumolu Y. Our surgical experience on familial adenomatous polyposis. Surgical Chronicles. 2015; 20(1):217-20.

7. Groden J, Thliveris A, Samowitz W, Carlson M, Gelbert L, Albertsen H, Joslyn G, Stevens J, Spirio L, Robertson M, Sargeant l, Krapcho K, Wolff E, Burt R, Hughes J.P., Warrington J, McPherson J, Wasmuth J, Le Paslier D, Abderrahim H, Cohen D, Leppert $M$, White $R$. Identification and characterization of the familial adenomatous polyposis coli gene. Cell. 1991;66(3):589-600.

8. Kita K, Wittmann T, Nathke IS, Waterman-Storer CM. Adenomatous Polyposis Coli on microtubule plus ends in cell extensions can promote microtubule net growth with or without EB1. Mol Biol Cell. 2006; 17(5): 2331-45.

9. Gayther SA, Wells D, SenGupta SB, Chapman P, Neale K, Tsioupra K, Delhanty JD. Regionally clustered APC mutations are associated with a severe phenotype and occur at a high frequency in new mutation cases of adenomatous polyposis coli. Hum Mol Genet. 1994;3(1):53-6.

10. Zhang Y, Lu G, Hu Q, Wang X, Li C, Mao Y, Cui M. A de novo germline mutation of APC for inheritable colon cancer in a Chinese family using multigene next generation sequencing. Biochem Biophys Res Commun. 2014;447(3):503-7.

11. Moisio AL, Järvinen H, Peltomäki P. Genetic and clinical characterisation of familial adenomatous polyposis: a population based study. Gut. 2002;50(6): 845-50.

12. Papp J, Kovacs ME, Matrai Z, Orosz E, Kásler M, Børresen-Dale AL, Olah E. Contribution of APC and MUTYH mutations to familial adenomatous polyposis susceptibility in Hungary. Fam Cancer. 2016;15(1):85-97.

13. Lucci-Cordisco E, Risio M, Venesio T, Genuardi M. The growing complexity of the intestinal polyposis syndromes. Am J Med Genet A. 2013;161A(11):2777-87.

14. Delaini $G G$, Skřička T, Colucci G. Intestinal polyps and polyposis. From genetics to treatment and follow up. Italia: Springer-Verlag, 2009: 246 p.
15. Heinimann $K$, Müllhaupt B, Weber W, Attenhofer $M$, Scott RJ, Fried M, Martinoli S, Müller H, Dobbie Z. Phenotypic differences in familial adenomatous polyposis based on APC gene mutation status. Gut. 1998;43(5):675-9.

16. Young J, Simms LA, Tarish J, Buttenshaw R, Knight N, Anderson GJ, Bell A, Leggett B. A family with attenuated familial adenomatous polyposis due to a mutation in the alternatively spliced region of APC exon 9. Hum Mutat. 1998;11(6):450-5.

17. Iwama T, Utsunomiya J. Anticipation phenomenon in familial adenomatous polyposis:an analysis of its origin. World J Gastroenterol. 2000; 6(3): 335-8.

18. McInnis $M G$. Anticipation: an old idea in new genes. Am J Hum Genet. 1996;59(5):973-9.

19. Ning XH, Zhang N, Li T, Wu PJ, Wang X, Li XY, Peng SH, Wang JY, Chen JC, Gong K. Telomere shortening is associated with genetic anticipation in Chinese Von Hippel-Lindau disease families. Cancer Res. 2014;74(14):3802-9.

20. Tabori U, Nanda S, Druker H, Lees J, Malkin D. Younger age of cancer initiation is associated with shorter telomere length in Li-Fraumeni syndrome. Cancer Res. 2007;67(4):1415-8.

21. Hsu L, Zhao LP, Malone KE, Daling JR. Assessing changes in ages at onset over successive generation: an application to breast cancer. Genet Epidemiol. 2000;18(1):17-32.

22. McFaul CD, Greenhalf W, Earl J, Howes N, Neoptolemos JP, Kress R, Sina-Frey M, Rieder H, Hahn S, Bartsch DK. European Registry of Hereditary Pancreatitis and Familial Pancreatic Cancer (EUROPAC); German National Case Collection for Familial Pancreatic Cancer $(\mathrm{FaPaCa})$. Anticipation in familial pancreatic cancer. Gut. 2006;55(2):252-8.

23. Goldberg JM, Piver MS, Jishi MF, Blumenson L. Age at onset of ovarian cancer in women with a strong family history of ovarian cancer. Gynecol Oncol. 1997;66(1):3-9.

24. Bertorelle R, Rampazzo E, Pucciarelli S, Nitti D, De Rossi A. Telomeres, telomerase and colorectal cancer. World J Gastroenterol. 2014;20(8):1940-10.

25. Horwitz M, Goode EL, Jarvik GP. Anticipation in familial leukemia. Am J Hum Genet. 1996; 59(5): 990-998. 
26. Wiernik PH, Wang SQ, Hu XP, Marino P, Paietta E. Age of onset evidence for anticipation in familial non-Hodgkin's lymphoma. Br J Haematol. 2000; 108(1):72-9.

27. Goldstein AM, Clark WH Jr, Fraser MC, Tucker MA. Apparent anticipation in familial melanoma. Melanoma Res. 1996;6(6):441-6.

28. Shibata D, Peinado MA, Ionov Y, Malkhosyan S, Perucho $M$. Genomic instability in repeated sequences is an early somatic event in colorectal tumorigenesis that persists after transformation. Nat Genet. 1994;6(3):273-81.

29. Bozzao C, Lastella P, Stella A. Anticipation in lynch syndrome: where we are where we go. Curr Genomics. 2011;12(7):451-65.

30. Seguí N, Pineda M, Guinó E, Borràs E, Navarro M, Bellido F, Moreno V, Lázaro C, Blanco I, Capellá G, Valle $L$. Telomere length and genetic anticipation in Lynch syndrome. PLoS One. 2013;8(4):e61286.

31. Makuch GW, Zastavna DV, Tyrkus MN, et al. Pat. 32044 Ukraine, IPC G01N33/49 (2006.01) Method of DNA isolation from peripheral blood leukocytes. patent owner SI "Institute of Hereditary Pathology of National Academy of Medical Sciences." N u200801896; appl. 14.02.2008; publ.25.04.2008, Bull. N8/2008.

32. Plawski A, Jura J, Slomski R. Wykrywanie mutacji punktowych w genie supresorowym APC czlowieka metod heterodupleksów. Przyklady analiz DNA, 2001: 80-9.

33. Plawski A, Lubinski J, Banasiewicz T, et al. Mutations in the APC gene were found in $42(35 \%)$ Polish families with FAP, and 22 types of mutation in the APC gene were identified. J Med Genet. 2004; 41: e11.

34. Atramentova LA, Belyaeva LV. Correlation between family and age of manifestation of lung and colon cancer. Genetika. 2003; 39(12):1702-9.

35. Sieber OM, Tomlinson IP, Lamlum H. The adenomatous polyposis coli (APC) tumour suppressor-genetics, function and disease. Mol Med Today. 2000;6(12):462-9. Review. Erratum in: Mol Med Today $2001 ; 7(1): 40$.

36. Aretz S, Uhlhaas S, Caspari R, Mangold E, Pagenstecher $C$, Propping $P$, Friedl $W$. Frequency and parental origin of de novo APC mutations in familial adenomatous polyposis. Eur J Hum Genet. 2004;12(1):52-8.

37. Castellsagué E, González S, Guinó E, Stevens KN, Borràs E, Raymond VM, Lázaro C, Blanco I, Gruber SB, Capellá $G$. Allele-specific expression of APC in adenomatous polyposis families. Gastroenterology. 2010;139(2):439-47, 447.e1.

38. Spier I, Horpaopan S, Vogt S, Uhlhaas S, Morak M, Stienen D, Draaken $M$, Ludwig M, Holinski-Feder E, Nöthen MM, Hoffmann P, Aretz S. Deep intronic APC mutations explain a substantial proportion of patients with familial or early-onset adenomatous polyposis. Hum Mutat. 2012;33(7): 1045-50.

40. Roger L, Jones RE, Heppel NH, Williams GT, Sampson JR, Baird DM. Extensive telomere erosion in the initiation of colorectal adenomas and its association with chromosomal instability. $J$ Natl Cancer Inst. 2013;105(16):1202-11.

41. Hoffmeyer K, Raggioli A, Rudloff S, Anton R, Hierholzer A, Del Valle I, Hein K, Vogt R, Kemler R. $\mathrm{Wnt} / \beta$-catenin signaling regulates telomerase in stem cells and cancer cells. Science. 2012;336(6088): 1549-54.

42. Calado RT, Yewdell WT, Wilkerson KL, Regal JA, Kajigaya S, Stratakis CA, Young NS. Sex hormones, acting on the TERT gene, increase telomerase activity in human primary hematopoietic cells. Blood. 2009; 114(11):2236-43.

43. Nanni S, Narducci M, Della Pietra L, Moretti F, Grasselli A, De Carli P, Sacchi A, Pontecorvi A, Farsetti $A$. Signaling through estrogen receptors modulates telomerase activity in human prostate cancer. J Clin Invest. 2002;110(2):219-27.

44. Wu KJ, Grandori C, Amacker M, Simon-Vermot N, Polack A, Lingner J, Dalla-Favera R. Direct activation of TERT transcription by c-MYC. Nat Genet. 1999;21(2):220-4.

45. Newbold RF. The significance of telomerase activation and cellular immortalization in human cancer. Mutagenesis. 2002;17(6):539-50.

46. Kyo S, Takakura M, Kanaya T, Zhuo W, Fujimoto K, Nishio Y, Orimo A, Inoue M. Estrogen activates telomerase. Cancer Res. 1999;59(23):5917-21. 
Сімейний аденоматозний поліпоз: зв'язок між віком виникнення і мутаціями гена $A P C$ для оцінки генетичної антиципації в паціснтів західних областей України

М. Р. Лозинська, Ю. С. Лозинський, А. Плавскі, Р. О. Піняжко, Н. М. Прокопчук, О. М. Федота

Мета. Визначити середній вік виникнення сімейного аденоматозного поліпозу (САП) у чоловіків, жінок, їх родичів, носіїв мутацій гена $A P C$, або ж у хворих без підтверджених мутацій цього гена, для оцінки антиципації у наступних поколіннях для раннього виявлення осіб групи ризику. Методи. Провели аналіз медичної документації, генеалогічної інформації та виконали молекулярно-генетичне дослідження крові в 25 пробандів із аденоматозним поліпозом. У 44,0 \% пробандів було підтверджено САП. Пробанди мали 36 родичів із цим синдромом. Ампліфіковані фрагменти гена $A P C$ були скриновані на наявність мутацій з використанням конформаційного поліморфізму однониткової ДНК, гетеродуплексного аналізу, а також аналізу кривих плавлення ампліконів із високою роздільною здатністю. Вік початку захворювання визначали в пробандів, їх родичів та рахували індекс антиципації (А). Результати. Серед пацієнтів із САП було 61,7 \% чоловіків і 38,3 \% жінок. Встановлено, що вік маніфестації синдрому в чоловіків становив $36,03 \pm 1,44$ років, а в жінок захворювання виникало раніше - у віці $29,5 \pm 2,43$ років $(p<0,01)$. Мутації гена $A P C$, включаючи 4 нові мутації, виявили в 63,6 \% пробандів із САП. Найменший вік виникнення поліпозу спостерігали в носіїв мутації c.3927_3931delAAAGA p.Q1309fs гена APC. Середня різниця у віці початку САП у батьків і їх потомства становила $12,0 \pm 1,7$ років. У 3 із 4 сімей із САП, члени яких були носіями нових мутацій, спостерігали переважання чоловічої статі (12:4) і явище антиципації, а один пробанд був носієм мутації, яка виникла de novo. Найсильнішу кореляцію за віком виникнення САП були знайдені в парах матері-нащадки і батьки-сини. Статистично значуща різниця між отриманими даними підтверджує більшу подібність нащадків, особливо синів, 3 батьками. Висновки. Між віком виникнення САП у пацієнтів, носіїв мутації гена $A P C(33.1 \pm 2.1$ років) і віком хворих, у яких не підтверджено мутацій цього гена

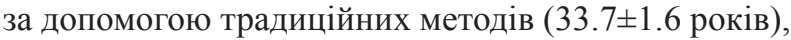
не було виявлено статистично істотної різниці. Індекс антиципації (А) у пацієнтів із САП дорівнював $18,0 \%$. У нащадків із САП зменшення віку виникнення захворювання порівняно з батьками не залежало від наявності мутацій гена $A P C$. Облік антиципації дозволяє оцінити середній вік початку САП під час генетичного консультування, i, отже, своєчасно здійснювати цільову профілактику.

Кл ю ч о в і с л о в а: антиципація, мутації гена $A P C$, вік початку виникнення САП у чоловіків і жінок, сімейний аденоматозний поліпоз.

\section{Семейный аденоматозный полипоз: связь} между возрастом возникновения и спектром мутаций гена $A P C$ для оценки генетической антиципации у пациентов западных областей Украины

М. Р. Лозинская, Ю. С. Лозинский, А. Плавски, Р. А. Пиняжко, Н. М. Прокопчук, О. М. Федота

Цель. Определить средний возраст начала семейного аденоматозного полипоза (САП) у мужчин, женщин, а также у родственников пробандов носителей мутаций гена $A P C$, или же у больных без подтвержденных мутаций этого гена, в последующих поколениях для оценки явления антиципации и для раннего выявления лиц групп риска. Методы. Провели анализ медицинской документации, генеалогической информации и выполнили молекулярно-генетическое исследование крови в 25 пациентов с аденоматозным полипозом. В 44,0 \% пробандов с полипозом было подтверждено САП. Пробанды имели 36 родственников с этим синдромом. Амплифицированные фрагменты гена АРС были скринированы на наличие мутаций с использованием конформационного полиморфизма однонитевой ДНК, гетеродуплексного анализа, а также анализа кривых плавления ампликонов с высокой раздельной способностью. Возраст начала заболевания определяли у пробандов, их родственников и вычисляли индекс антиципации (А). Результаты. Среди пациентов из САП было 61,7 \% мужчин и 38,3 \% женщин. Усновлено, что возраст начала синдрома в мужчин составлял 
$36,03 \pm 1,44$ лет, а у женщин заболевания возникало раньше - в возрасте 29,5 $\pm 2,43$ лет ( $p<0,01)$. Мутации гена $A P C$, включая 4 новые мутации, обнаружили в 63,6 \% пробандов из САП. Наименьший возраст возникновения полипоза наблюдали у носителей мутации c.3927_3931delAAAGA p.Q1309fs гена АРC. Средняя разница в возрасте начала САП у родителей и их потомства составила $12,0 \pm 1,7$ лет. У 3 из 4 семей из САП, члены которых были носителями новых мутаций, наблюдали преобладание мужского пола (12:4) и явление антиципации, а один пробанд был носителем мутации, которая возникла de nоvo. Самую сильную корреляцию по возрасту возникновения САП было найдено в парах матери-потомки и родители-сыновья. Статистически значимая разница между полученными данными подтверждает большее сходство потомков, особенно сыновей, с родителями. Выводы. Между возрастом возникновения САП у пациентов, носителей мутаций гена $A P C(33.1 \pm 2.1$ года), и возрастом больных, у которых не подтверджено мутаций этого гена с помощью традиционных методов $(33.7 \pm 1.6$ года), не было выявлено статистически значимой разницы. Индекс антиципации у пациентов из САП равнялся $18,0 \%$. У потомков из САП уменьшение возраста возникновения заболевания по сравнению с родителями не зависело от наличия мутаций гена $A P C$. Учет антиципации позволяет оценить средний возраст начала САП при генетическом консультировании, и, следовательно, своевременно осуществлять целевую профилактику.

Кл юч е в ы е сл ов а: антиципация, мутации гена $A P C$, возраст начала САП у мужчин и женщин, семейный аденоматозный полипоз.

Received 15.12.2016 